\title{
В.В. Рожков
}

Новосибирский государственный педагогический университет

\author{
Сравнительный анализ фрагментов \\ усредненной и индивидуально-авторской картин мира \\ (на материале лексикографических источников \\ и произведений А. и Б. Стругацких)
}

Цель этой статьи - выявление универсального и специфичного в концепте, вербализованном лексемами «серый, серость». Для этого необходимо смоделировать концепт в картине мира социума, и сравнить его с художественной картиной мира, объективированной в тексте братьев Стругацких «Трудно быть богом».

Для конструирования фрагмента национальной картины мира обратимся к лексикографическим источникам.

Концепт «Серость» состоит из базового концептуального слоя (чувственного образа), основных концептуальных слоев (КС) «Погода», «Посредственность» и «Малокультурность, необразованность», имплицитных слоев (составляющих интерпретативную часть концепта) «Непонятный, подозрительный», «Бедный, простой, безответный» и «Болезнь, страдание». Остановимся на каждом из КС более подробно.

Зрительный образ, т.е. цвет дается во всех толковых словарях как первое значение: «Цвета, получаемого из смешения черного с белым». Как и следовало ожидать, реакции с семантикой цвета (в основном предметная лексика) составляют в Русском ассоциативном словаре под редакцией Ю.Н. Караулова (РАС) большинство (в среднем $60 \%$, если судить по нечетным томам (от стимула к реакции)), хотя здесь существует интересная закономерность: в статье со стимулом серая цветовых реакций $84 \%$, со стимулом серый - $75 \%$, со стимулом серость $21 \%$.

Серым могут быть названы погода, физическое состояние в природе, время суток, нелокализованное пространство в случае, если все выше перечисленное соответствует условиям: недостаток света; осадки и обилие влаги (выполнение этого условия необязательно). Этот КС позволяют выделить, в частности, материалы словаря синонимов (пасмурныци, сумрачныцй, хмурый, тусклый) и РАС (облака, сумерки, туча, туман, рассвет, сырость, дождь, дождливый день, погода, небо, на улице).

КС «Посредственность». Концептуальная область (обозначает, для категоризации какого класса предметов служит данный концепт или концептуальный слой): «о человеке, его речах, мыслях, артефактах, месте, времени, образе жизни». Эта концептуальная область обнаруживает тенденцию к дальнейшему расширению. Концептуальные признаки (КП), общие для всех перечисленных в концептуальной области предметов и явлений: «ничем не выделяющийся из ряда таких же предметов и явлений», «интенсивное отрицательное эмоциональное отношение» (дефиниция в Словаре синонимов А.П. Евгеньевой - «лишенный выразительности, своеобразия, яркости, ничем не привлекающий внимания»), «легкость распознавания» (РАC - неприкрытая, очевидная), а также «вызывающий скуку». 
Для некоторых предметов и явлений выделяются отдельные КП. Так, серым можно назвать:

1) человека и продукт его деятельности, не привлекающих внимания, а значит, не вызывающих интереса; незамысловатого, «упрощенного» (РАC - проcmoтa), незавершенного в каком-либо отношении (РАC - заготовка), а также человека, лишенного всяческого таланта, природного дара (РАC - бездарность, Словарь антонимов - талант), незначительного. При этом созданию образа «серости» способствует большое количество, скопление кого-, чего-нибудь в случае, если люди или предметы в этом скоплении обладают общими признаками, свой ствами (РАС - толnа, масса, стадо (о скоплении людей), Словарь фразеологизмов - серая скотинка (о солдатах в дореволюционной России)). Также серым может быть назван человек, выполняющий, в нашем представлении, определенную функцию, работу, лишенную своеобразия (РАС - служащиий, клерк);

2) серым можно назвать какой-нибудь отрезок времени или какое-нибудь место (либо и то, и другое одновременно) и образ жизни (о расширении КО свидетельствуют реакции город, на улице, сегодняшнего дня, жизнь, быт), если события и поступки человека повторяются изо дня в день, при этом они лишены яркости, своеобразия, все остается неизменным (РАС - будни, повседневность, обыденность, рутина). Для такого образа жизни языковым сознанием отмечается также трудность выхода из него, губительное воздействие на новое, своеобразное, попадающее в сферу такого образа жизни (РАС - болото, непроходимая).

Этот КС оказался одним из самых представленных лексической системой языка, а значит, и одним из наиболее актуальных.

КС «Малокультурный, необразованный». Концептуальная область: «о человеке, его ментальной и духовной сфере». Для того чтобы назвать человека серым, он должен быть: совершенно не имеющим образования (имеющим плохое образование); плохо владеющим производственными, общественными, духовными достижениями людей или не принимающим их; обладающим низкими нравственными качествами (Малый академический словарь в 4-х т.: «невежественный, малокультурный»). Такой человек оценивается негативно, причем здесь есть элементы рациональной оценки, обосновывающие неодобрение: «несовершенный», «отклонение от нормы в худшую сторону», «более низкий уровень развития по сравнению с другими людьми» (РАС - отсталость, тупость, необразованный). Причинами «серости» могут быть: умственная ограниченность (т.е. неспособность к получению образования и усвоению культуры), провинциальность (удаленность от источников образования и культуры; РАС - деревенский, деревня). Следствиями «серости» могут быть: чрезмерная уверенность в себе, отсутствие сомнений, раздумий, пренебрежение к другим, грубость, неделикатность (РАС заносчивыци, ненависть, грубость), а также отсутствие интереса к такому человеку со стороны других (РАC - неинтересный). Поступки и мотивы такого человека легко объяснимы. Для этого КС так же, как и для КС «Заурядный» актуальны когнитивные признаки «трудность выхода из этого состояния», «легкость распознавания необразованности и некультурности».

Кроме базовых КС, зафиксированных в толковых словарях, в содержании концепта есть скрытые, неявные КС, выявленные по материалам РАС, на основе паремий и маргинальной лексики.

КС «Непонятный, подозрительный». Например, пословицы из словаря В.И. Даля: говорит красно, а выходит серо (мутно, непонятно); есть в нем серой шерсти клок. В Словаре тюремно-лагерно-блатного жаргона приводится такое значение слова серый: 2. Подозрительный, не вызывающий доверия человек.

КС «Бедный, простой, безответный». Например, вали на серого, серый все свезет (актуальный смысл, данный в словаре: «безответный, тот, кто не может ответить»). РАС: бедность, грязь, нищета, убогость. 
КС «Болезнь, страдание». Здесь следующие реакции: больница, болезнь, неизлечима, страдание, мучение, горе, кровать, мокрота, не хочу, поганка. Необходимо заметить, что в словарных статьях РАС содержится немало оценочной лексики, причем только негативной. Отметим также негативную оценку в предыдущих КС. КС «Болезнь, страдание» конкретизирует эту оценку и воплощает ее в себе.

Теперь обратимся к художественной картине мира. В тексте А. и Б. Стругацких основным средством выражения концепта являются метафоры и метафорическая организация текста в целом. Моделирование метафорического поля при анализе текста - не универсальный путь, однако данный текст построен на основополагающих метафорах. Важнейшую роль в его организации играют ключевые метафоры серость, трясина и бог. Метафора как явление языка, а, по мнению Дж. Лакоффа и М. Джонсона, и явление мышления [Лакофф, Джонсон, 1990], обладает целым набором свойств. Среди важнейших из них исследователи отмечают антропометричность, образность, сложность семантической организации. Важнейшим свойством метафоры является то, что она может выступать как средство концептуализации действительности. О когнитивной метафоре пишут В.Н. Телия [Телия, 1988], А.П. Чудинов [Чудинов, 2004] и др. То, что метафора играет важнейшую роль в организации данного текста, позволяет конкретизировать текстообразующую функцию метафоры, выявленную В.К. Харченко [Харченко, 1992].

Действие повести происходит в эпоху феодального средневековья на чужой планете, куда попадает в качестве наблюдателя землянин - коммунар и гуманист. Именно он «примеряет» на себя роль бога.

В соответствии с задачами авторов и проблематикой произведения в текстовом концепте, объективированном лексемами «серый, серость» наиболее востребованным оказывается концептуальный слой «Необразованность, малокультурность», а также неявный концептуальный слой «Болезнь, страдание». Интересно, что в тексте по-своему реализуется базовый концептуальный слой «Цвет» - повесть выдержана в серых тонах, серого цвета здесь очень много. Базовый концептуальный слой является семантическим стержнем концепта «Серость» в языковом сознании, точно так же в лексическом значении слова серый значение цвета первично, на его основе развиваются все остальные значения, что объясняется большим ассоциативным потенциалом семантики цвета. В тексте, кроме многочисленных прямых, номинативных употреблений обозначения серого цвета при отсутствии упоминаний других цветов (серые глаза, солдаты, штурмовики, офицеры, серое утро, серая бородка, серый туман), есть косвенные обозначения цвета с помощью слов, в лексическом значении которых есть сема «серый» (тучи, темнота, пьль, туман). Все это создает определенную атмосферу, фон, на котором развиваются смыслы, связанные с семантикой серости. Показательны здесь следующие контексты: перед ним лежала страна, накрытая одеялом комариных туч, раздираемая оврагами, затопляемая болотами, пораженная лихорадками и зловонными насморками (употребление слов в переносном значении - одеяло «плотный, непроницаемый покров», туча «множество, скопление, густая, серая движущаяся масса», раздираемый «причиняющий боль, страдание» в одном контексте ассоциативно создает смыслы «духота, отсутствие света, страх, боль, разрушение»; другой контекст один я вижу наползающую на страну тень передает смыслы «угроза», «страх», «темнота»). Хотя серый - это смешение белого и черного, однако в сознании человека серый цвет связывается скорее с темным, чем со светлым [Ермоленкина, 2003].

Метафорическая тема «серость» включает в себя еще один компонент, который в соответствии с ключевыми словами можно назвать «топь, трясина» (напри мер, поднялась серая топь; в сумеречной невежественной стране, погрязшей в 
кровавой трясине заговоров и корыстолюбия; а ведь ходим по краешку трясины, оступился - и в грязь, всю жизнь не отмоешься).

Все контексты, относящиеся к этим метафорическим темам и репрезентирующие текстовый концепт «Серость», распределены по трем большим группам: «неразвитость», «агрессивность», «губительное воздействие».

Нагнетание серого цвета, тяжелой атмосферы в сочетании с группой контекстов, объективирующих концептуальный признак «тупость, ограниченность», «деградация» (трещат их тупье, примитивные мозги в тщетном стремлении угнаться за смыслом слов и поступков этого согбенного старичка; толпы слеnыx, одурманенных, не знающих сомнения людей) дают логическое развитие концептуальному слою «агрессивность» (организованное зверство и напирающая сеpocmb). В создании этого смысла важную роль играет и то, что агрессивные действия в тексте, как правило, совершаются толпой, массой.

Подробно не останавливаясь на этом, отметим, что серость в контексте повести обретает новое значение - «идеология, нравственный эталон общества», которое выражается употреблениями ключевых лексем (например, всем сердием предан серому слову и серому делу; он не знает, что такое серый террор, $и$ когда я говорю ему о фашизме, о серых итурмовиках, об активизачии мещзанства он воспринимает это как эмоциональные выражения).

На наш взгляд, текстовый концепт в повести Стругацких обладает одним интересным свойством - процессуальностью. Все концептуальные признаки в его концептуальных слоях можно выстроить в определенной логической последовательности: концептуальный слой «неразвитость» - «ограниченность», «тупость», «деградация», «предельная простота организации», «часть механизма» (здесь происходит усугубление признака); концептуальный слой «агрессивность» - «потенциальная угроза» и «хищный, звериный, нечеловеческий», затем «физическое или психическое воздействие», наконец «результат агрессии, физическое уничтожение» и «жертва агрессии»; концептуальный слой «губительное воздействие» «духота, беспросветность», «делать неподвижным, сдавливать, стеснять», затем «болезненное состояние», далее «развитие болезни», наконец «грязь, потеря человеческого облика».

Развитие также происходит на уровне сюжета: власть серых в обществе сменяет власть черных монахов (в тексте: там, где торжествует серость, к власти всегда приходят черные).

Таким образом, сравнение усредненной и художественной картин мира позволяет выявить универсальные и специфичные признаки концепта.

\section{Литература}

Лакофф Дж., Джонсон М. Метафоры, которыми мы живем // Теория метафоры. М., 1990.

Телия В.Н. Метафоризация и ее роль в создании картины мира // Роль человеческого фактора в языке: Язык и картина мира. М., 1988.

Чудинов А.П. Учение о метафоре в когнитивной лингвистике // Проблемы языковой концептуализации и категоризации действительности. Екатеринбург, 2004.

Харченко В.К. Функции метафоры. Воронеж, 1992.

Ермоленкина Л.И. Цветовая маркировка как способ выражения этической и эстетической оценок (на материале диалектной метафорической лексики) // Картина мира: модели, методы, концепты. Томск, 2003. 